\title{
Grundtvig i dag
}

\section{Af William Michelsen}

Vartovbogen 1990. Kirkeligt Samfunds forlag, København. 88,25 kr.

Vil man vide, hvordan det er muligt for et tænkende menneske i dag at være kristen, skal man læse Vartovbogen. Den redigeres ganske vist af tre præster, men dens forfattere er ikke blot teologer. I den seneste årgang er fem af de elleve forfattere af anden uddannelse og livsstilling: 2 gymnasielærere, 1 direktør, 1 museumsinspektør og 1 analytisk psykolog. Det tyder på fornyelse. Der er ikke meget at hente for Grundtvigforskningen, men des mere for videreførelsen af Grundtvigs tanker om menneskelivet i dag, f.eks. Helge Grells artikel om forskellen mellem det nationale og det folkelige såvel hos Grundtvig som rundt omkring i verden i dag.

Når Laue Traberg Smidt går så vidt som at kalde "Danmarks selvstændige landets frelse «, skyldes det især at han anser »de mindre virksomheders kamæleonagtige måde at tilpasse sig en fri efterspørgsel på« for »den grundlæggende årsag til vores velstand.« Han vil ikke påtvinge os den livsform, han selv foretrækker, men hævder, »at det bør være en reel valgmulighed for nogle flere mennesker at tilbringe en del af livet som selvstændig næringsdrivende.« Han henviser med god grund til erfaringerne fra Østeuropa, som først nu skal tilpasse sig markedsøkonomiens hårde vilkår. Og Gudrun Aspel viser i sin beskrivelse af voksenundervisningscentret Skærum Mølle, hvordan familien Villemoes med udgangspunkt i stifterens højskoleophold på Askov i 1869 stadig fortsætter virkeliggørelsen af Grundtvigs højskoletanker.

Men det er ikke blot i det praktiske liv, Grundtvigs menneskesyn viser sig brugbart. Jakob Fløe Nielsen skriver om »Det underbevidste set fra en prædikestol « og Pia Skogemann om »Drømme i Bibelen«. Jeg tror, at de er nærmere ved Grundtvigs menneskesyn, end de selv synes at være klar over. Fløe Nielsen skriver ligefrem, at det er »til forskel fra Grundtvig «, han hævder, »at det er fortællingen om og forkyndelsen af Jesus som det sande menneske, der i dag kan hjælpe os til at få øje på det menneskelige liv, vi er i fuld gang med at lade os franarre.« Hvorfor »til forskel fra Grundtvig«?

En artikel af Søren Agersnap har overskriften "Evangeliet om et nyt frugtbart liv«. Den viser sig at handle om den nye oversættelse af Romerbrevet efter min mening den mest ulæselige tekst $\mathrm{i}$ Det nye Testamente, når man ikke er teolog. Agersnap giver imidlertid læseren blod på tanden ved at give et overblik over teksten, som er helt nødvendigt, hvis man skal kunne forstå den. Og går man til teksten selv, viser den sig forbløffende nok i den nye oversættelse af være blevet læselig, forståelig og spændende. Det hænger bl.a. sammen med, at man nu tydeligere kan se, at Paulus argumenterer mod »en fiktiv jøde « og dermed udelukker en fundamentalistisk fortolkning. Men hvem er denne »fiktive jøde «? - Er det ikke Paulus selv? - Hvis indledningen til »Nordens Mythologi« 1832 er »Grundtvigs opgør med sig selv«, er Romerbrevet så ikke Paulus's opgør med sig selv? I så fald bliver det lettere at forstå, hvorfor begge de to tekster på én gang er så vigtige og så vanskelige at læse og forstå. Der må være tale om en virkelig dialog inde i forfatteren selv. 
En anden artikel - af Finn Jacobi - handler meget direkte om kristendom og seksualitet med udgangspunkt i vielsesritualet, men uden ændringsforslag. Den gennemgår i stedet hvad Paulus og Jesus har at sige om seksualiteten. Det er ikke moderne tanker. Jacobi går helt tilbage til Adam og Eva. Havde de samleje i paradiset? Han viderefører en tanke fra 800-tallets "førende teolog « Johannes Scotus Erigena. »Det, der skete ved syndefaldet, var åbenbart, at seksualdriften blev unddraget viljens herredømme, « skriver Jacobi. »Satser man på viljen, bliver man gjort til skamme, « siger han. Men han vil ikke gå med til, at dét kompromitterer den fysiske side af kærligheden. $\mathrm{Og}$ i den anledning inddrager han en sammenligning med muhammedansk tankegang, som er helt forskellig fra den kristne. Jeg må give Jacobi ret, når han skriver: "Dybest set lægger man vel sit liv i Guds hænder, når man lader driften tage magten..." Men denne tanke er os fremmed som kristne. Det burde den ikke være. Men Paulus har i den grad præget vores kulturelle mønster, at vi bliver nødt til at frigøre os fra ham på dette punkt for at finde tilbage til Jesu oprindelige evangelium. - Sagen er jo den, at Paulus ventede Jesu genkomst og derfor fandt ægteskabet overflødigt. Sådan kan vi ikke se på det. Vi må i stedet finde et naturligt kristent syn på seksualiteten. Og en antydning deraf giver Jacobi i slutningen af sin artikel.

Grundtvig skammede sig ikke over sine forelskelser. Men derfor behøver man ikke - som Ebbe Kløvedal Reich i Vartovbogens næstsidste årgang - at forestille sig, at han »horede « med Clara Bolton. Grundtvig satte fem sunde børn i verden med sine tre hustruer, den ene efter den anden og uden at bryde ægteskabet. Det var trods alt Lise Blicher, der lærte ham, at "Kvinden hun er Livet i Huset «, som det hedder i Sang-Værk II nr. 13, digtet 1825. Og det var Lise, der simpelthen blev vred over, at hendes mand ikke tog imod Clara Boltons indbydelse og besøgte hende: »tænk dig f. Eks. Fru Rahbek eller Fru Bruun«, skriver hun til ham (Englandsbreve, s. 105). - Med Marie Toft var det en anden sag for Lise.

Vartovbogen er en smuk bog. I de senere år har den været illustreret af kunstværker med eller uden direkte forbindelse med indholdet. I denne årbog er det grafik af Kirsten Dissing Overgaard, som tillige er valgmenighedspræst. Hendes arbejder er vinterbilleder, der viser samspillet mellem jord og himmel, vand og vækster, men uden blade, uden farver og kun med svage antydninger af sol og skygge. Over for slutningen af Jacobis artikel er sat nogle få træer foran tre højhuse. Billedet står overfor sætningen: „En gudsforståelse, der river natur og kultur fra hinanden, kan ikke være sand.«

Vilhelm Nielsen: Omkring Grundtvigs "Paaske-Lilien". I Dansk Udsyn, udg. af Askov Højskole, 6 hefter, 240 kr. pr. år.

Det sidste dobbeltnummer af dette tidsskrift (nr. 5-6) indeholder bl.a. en artikel om »Paaske-Lilien « af den mangeårige undervisningsinspektør for folkehøjskolerne, Vilhelm Nielsen, en artikel, der har stor interesse for Grundtvigforskningen, fordi den ikke blot på mønsterværdig måde gør rede for de forskellige tolkninger, dette lyrisk-dramatiske digt har været genstand for, men dernæst stiller det $\mathrm{i}$ forhold til det digt, der følger umiddelbart efter i Danne-Virke II: »Nytaars-Nat, (en Drøm)«, som tidligere har været behandlet af professor Aage 
Henriksen, bl.a. i »Gotisk tid«, anmeldt i Grundtvig-Studier 1971. - Kun denne artikel er tilsendt i særtryk af forfatteren, men der er god grund til at gøre opmærksom på hele tidsskriftet, der redigeres af en kreds af Askov Højskoles lærere og dens rektor. Grundtvig ønskede en naturlig vekselvirkning mellem den folkelige højskole og den videnskabelige, universitetet. Det gør GrundtvigSelskabet også - men nu må det hedde folkehøjskolerne og universiteterne og deres centre.

Det spændende ved Vilhelm Nielsens sammenstilling af de to digte er, at han ser "Paaske-Lilien « som »et svar på det spørgsmål, som ligger bag "NytaarsNat «, selvom de to digte blev trykt i omvendt rækkefølge.« - Dette spørgsmål ligger i omkvædet på »Nytaars-Nat«: "Hvad har dog den Drøm at betyde?« Hvad man drømmer nytårsnat har fra gammel tid været tillagt særlig betydning. Men denne drøm drejer sig om Danmarks historie, landets fortid og dets fremtid. Det er og bliver en drøm, mens vi i »Paaske-Lilien« møder den vågne og bevidste Grundtvig, siger Vilhelm Nielsen.

Men i modstillingen af de to digte møder vi tillige de to hovedinteresser i Grundtvigs liv: kristendommen og historien. Og disse to interesser meldte sig i omvendt rækkefølge. Historieinteressen kom først. Kristendommen så Grundtvig som et led i verdenshistorien og i de enkelte landes historie og dermed i Danmarks historie. Således gik det også i Grundtvigs liv. Vel var han af sine forældre bestemt til at blive præst, men han ønskede først og fremmest at blive historiker, og hvorfor? - For at genopvække »de gamle Heltedage « til nyt liv $\mathrm{i}$ nutiden. Er det muligt? - Skal vi følge Vilhelm Nielsens opfattelse af »PaaskeLilien«, er svaret ja. Kristendommens historie i verdenshistorien viser det. Det var i den kristne kirke, Jesus genopstod fra de døde. Hans evangelium døde ikke på korset. Det lever i kirken den dag i dag.

At Grundtvig tænkte sådan, tror jeg Vilhelm Nielsen har ret i. Om vi andre kan tænke ligesådan, er en anden sag. Vi er meget tilbøjelige til at tænke rationalistisk:

Stod Han op, som Ordet gaaer!

Mon hans Ord igien opstaaer!

Men sådan tænkte Grundtvig ikke. For at citere Vilhelm Nielsen:

"Måske kunne man sige det på den måde, at rammedigtet ikke argumenterer for Jesu opstandelse, men med Jesu opstandelse. Jesu opstandelse er for Grundtvig før, under og efter digtet en given kendsgerning. Spørgsmålet er, hvad den betyder, hvilken virkning den har, in casu på historien.« (Dansk Udsyn 1990, s. 259)

Man kunde også sætte fingeren på udråbstegnene efter de to citerede linier af digtet. Grundtvig satte ikke spørgsmålstegn. Det var samtiden, det er os, der er tilbøjelige til at tænke sådan. - Men argumentet gælder ikke. Sætningsformen er et spørgsmål. Men svaret kommer straks i den følgende strofe:

Kan de Døde ei opstaae, 
Intet har vi at betyde,

Visne maa vi brat i Vraa,

Ingen Have skal vi pryde.

Tvivlen i »Paaske-Linien « - for der er en tvivl - gælder ikke Jesu opstandelse, men vor egen: vi ser jo påskeliljerne visne, de pryder ikke haven i længden:

Glemmes skal vi under Muld,

Vil ei Voxet underfuld

Smelte, støbes i det Dunkle,

Og som Lys paa Graven funkle.

Ifølge Vilhelm Nielsen handler »Paaske-Lilien« imidlertid ikke om troens problem, men om Grundtvigs "problem som historiker: at levendegøre de døde fædre«. »Måske kan man sige, at »Paaske-Lilien« er et fortvivlet forsøg på at forene de to linier $\mathrm{i}$ hans forfatterskab: Historie og Kristendom. Den sidste er den nødvendige betingelse for, at den første kan nå sit mål: at de døde helte bliver mere end spøgelser og genfærd.« - Som de var i drømmen nytårsnat. Han gør opmærksom på, at også Hans Brix har været opmærksom på sammenhængen mellem de to digte. Men Vilhelm Nielsen har på en ny måde gennemført sin fortolkning sådan, at mange enkeltheder, f. eks. den "Rosenborg «, der pludselig dukker op i slutningen af »Paaske-Lilien«, făr sin naturlige forklaring: i drømmen var slottet skuepladsen for den dåb af Danmarkshistoriens personer, digteren skulde beskrive. I Aage Henriksens fortolkning bliver »Nytaars-Nat « et svar til Baggesen, hvori »Paaske-Lilien« ikke spiller hovedrollen. Vilhelm Nielsen slutter sig nærmest til den seneste fortolker af »Paaske-Lilien «, Erik A. Nielsen, der ser digtet som et forspil til Grundtvigs salmedigtning. - Også de øvrige fortolkere tager Vilhelm Nielsen stilling til uden at gøre nogen uret. Det er inspirerende læsning.

\section{Grundtvig og Kierkegaard}

\section{Af Hellmut Toftdahl}

Otto Bertelsen: „Dialogen mellem Grundtvig og Kierkegaard». C.A. Reitzels Forlag, Kbh. 1990. 129 sider.

Sammenligningen mellem Kierkegaard og Grundtvig har fristet mange. Den har ført til vidt forskellige konklusioner angående ligheder og forskelle. At sammentænke dem i et bud på, hvad de tilsammen har udrettet og stadig betyder for dansk teologi og kulturdebat, er en udfordring, som nok vil blive taget op med 